\author{
Entre verdade e encenação: 0 fotojornalismo \\ entre 0 documento e a expressão
}

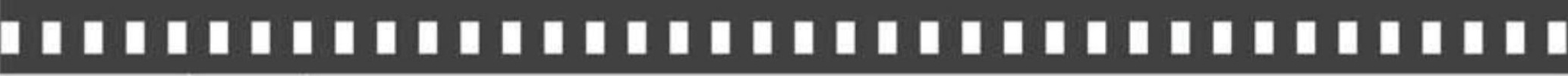

\author{
Laura Duarte Uliana \\ Simonetta Persichetti
}

Artigo recebido em: 22/05/2018

Artigo aprovado em: 03/10/2020 


\title{
Entre verdade e encenação: \\ o fotojornalismo entre o documento e a expressão
}

\author{
Between truth and staging: \\ the photojournalism between the document and the expression
}

\author{
Laura Duarte Uliana* \\ Simonetta Persichetti**
}

Resumo: Neste artigo, pretende-se analisar duas correntes de pensamento sobre a imagem fotográfica, a fotografia-documento e a fotografia-expressão, como pensadas por André Rouillé, e verificar suas influências no fotojornalismo. Para conversar com Rouillé, usaremos o conceito "isso foi", do Roland Barthes, e "isso foi encenado", de François Soulages. Com isso, analisaremos dois produtos: a revista Life e a agência Magnum, cada uma como principal expoente da corrente de pensamento na qual está inserida.

Palavras-chave: Fotojornalismo. História da fotografia. Agência Magnum. Revista Life.

\begin{abstract}
In this paper, I intend to analyze two currents of thoughts about the photographic image, the photographydocument and the photography-expression, by André Rouillé, and verify its influences on photojournalism. To establish a dialogue with Rouillé, we will use the concept of "that-hasbeen", from Roland Barthes, and "that-has-been-staged", from François Soulages. Using that, we will analyze two products: Life magazine and Magnum agency, each one as the leading exponent of the line of thought in which is inserted.
\end{abstract}

Keywords: Photojournalism. History of photography. Magnum agency. Life Magazine.

* Mestra em Comunicação pela Faculdade Cásper Líbero.

** Doutora em Psicologia Social pela Pontifícia Universidade Católica de São Paulo (PUC-SP). Professora do Programa de Pós-Graduação em Comunicação da Faculdade Cásper Líbero. 


\section{Introdução}

Roland Barthes (1915-1980), em seu livro "A câmara clara" (2012), postula que a fotografia é um sistema de produção de imagem o qual comprova que o referente existira; em suas palavras: "a essência da fotografia consiste em ratificar o que ela representa" (BARTHES, 2012, p. 79), ou seja, a fotografia é a prova de que "isso existiu", ou "isso foi". Ela, para Barthes (2012), é simplesmente uma cópia de seu referente, sem nenhuma interferência humana; a ideia de "autoria" em fotografia, de "estilo" de um fotógrafo, merece ser colocada em discussão.

Essa fotografia que acredita representar seu referente excluindo totalmente a subjetividade do autor é a fotografia-documento, nome dado por André Rouillé (1948), professor assistente na Universidade de Paris VII e editor-chefe do primeiro periódico dedicado exclusivamente à pesquisa e à reflexão em fotografia, La Recherche Photographique, em seu livro "A fotografia: entre documento e arte contemporânea” (ROUILLÉ, 2009).

A fotografia surgiu na sociedade pós-industrial, em um período conhecido como "era da máquina", no qual imperavam ideologias positivistas e cientificistas e, de maneira superficial, as pessoas acreditavam apenas naquilo que seus olhos viam. Por isso, precisava-se de um aparato que desse conta de reproduzir imagens de maneira mais rápida do que a pintura e, ao mesmo tempo, mais adequado aos valores desta sociedade. A “imagem-máquina” abolia a mão do homem e equivalia legitimamente às coisas que ela representava.

Segundo Rouillé (2009), sua credibilidade se dá, ao contrário 
do desenho e da pintura, por não "sacrificar" elementos do enquadramento a fim de melhor destacar as partes principais; além disso, a fotografia era tomada de uma só vez, se adequando melhor ao tempo do homem moderno. Porém, ainda segundo Rouillé (2009), não bastava apenas a confiança para sustentar a crença em fotografia: assim como a moeda, precisava-se de circulação. Foi em 1850, com a invenção dos Cartes de Visite ${ }^{1}$ pelo fotógrafo retratista francês André Adolphe Eugène Disdéri, que mais camadas da população tiveram suas imagens "eternizadas" por uma câmera.

A fotografia-documento teve grande expressão na reportagem clássica, que valia-se da concepção de que a imagem fotográfica era a reprodução exata de um referente preexistente, voltando na essência do "isso foi”, de Roland Barthes (2012). Para a fotorreportagem do século XX, que teve sua maior expressão entre a década de 1920 e a Guerra do Vietnã, esta ideia contribuía para a propagação da ideologia dos veículos de imprensa através das imagens, afinal, a fotografia mostrava apenas a realidade, sem filtros nem ideologias.

As revistas fotográficas eram as maiores plataformas de difusão das fotorreportagens. Surgidas na República de Weimar (19181933) na Alemanha, estas revistas eram inovadoras ao propor maior enfoque nas imagens. Inspirado por estas revistas, assim como pela revista francesa $V u$, o editor de revistas Henry Luce (1898-1967) decidiu criar a Life, revista semanal com grandes fotorreportagens. Com mais de 40 milhões de leitores em 1965, o periódico tinha gran1 Os Cartes de Visite foram a primeira forma de propagação da fotografia e foi inovador por baratear os custos da reprodução de um retrato. Disdéri patenteou, em 27 de novembro de 1854, o processo, que fora tornado possível por uma câmera com quatro lentes, que formavam quatro imagens na placa de vidro; esta posteriormente era deslocada para a obtenção de outras quatro fotografias; depois, elas eram copiadas com a técnica de reprodução em albumina. 
de influência sobre o público norte-americano.

O editor de fotografia John G. Morris (1916-2017) descreve, em seu livro "Get the Picture: A Personal History of Photojournalism" (MORRIS, 2002), o "sistema Life": as imagens dimensionavam a história e tinham maior destaque em relação ao texto escrito. Além disso, para ser fotojornalista da revista, não precisava de formação acadêmica; alguns dos fotógrafos não tinham ao menos o Ensino Médio completo.

Em 1934, Luce circulou um prospecto divulgando a ideia da nova revista, que será tomado como base para análise a partir das ideias de fotografia-documento, de André Rouillé (2009), e para o estabelecimento de um contraponto entre as teorias do "isso foi", de Roland Barthes, e do "isto foi encenado", de François Soulages. Segundo o prospecto, incluso em uma edição comemorativa da Life de 1938:

Para ver a vida; para ver o mundo; para ser testemunha ocular de grandes eventos; observar o rosto dos pobres e os gestos dos ricos; para ver coisas estranhas - máquinas, exércitos, multidões, sombras na selva e na lua; para ver o trabalho do homem - suas pinturas, torres e descobertas; para ver coisas distantes. Coisas escondidas entre paredes e dentro dos quartos, coisas perigosas de aproximar-se; as mulheres que os homens amam e muitas crianças; para ver e ter prazer em ver; para ver e ficar admirado; para ver e ser instruído; tanto ver quanto ser visto é agora o desejo e nova expectativa de metade da humanidade. Para ver e fazer ver é a missão assumida por um novo tipo de publicação. $^{2}$ (LIFE, 1938, p. 1).

2 "To see life; to see the world; to eyewitness great events; to watch the faces of the poor and the gestures of the proud; to see strange things - machines, armies, multitudes, shadows in the jungle and on the moon; to see man's work 
"Ver a vida" e "ver o mundo", assim como ver "coisas perigosas de aproximar-se" e "coisas distantes" como um todo remete à ideia sustentada por Rouillé (2009) de que "a relação, às vezes perigosa, vivida com o mundo é delegada a um terceiro (o fotógrafo) e substituída pela relação visual com as imagens" (ROUILLÉ, 2009, p.101). Por isso, acaba-se tendo uma visão mediada do mundo, não compatível com a experiência real. Mas, ao acreditar no "isso foi", exclui automaticamente a subjetividade do fotógrafo e a ideologia da revista na hora de olhar a foto, tornando mais fácil uma "manipulação" dos leitores.

A relação com o mundo fora mudada, mediada pelas fotorreportagens, pela fotografia-documento. Tomemos a cobertura da Life sobre a Guerra do Vietnã (1955-1975) como exemplo: os norte-americanos sabiam o que estava acontecendo nos campos de batalha pelas páginas da revista, mas apenas os soldados a viviam diretamente, até por ela não acontecer em seu território. Diversos protestos ocorreram, em partes, graças à extensa cobertura feita pela Life, mas não pela vivência real da guerra. Mas, apoiados pela fotografia-documento, acreditavam fielmente no que era mostrado como substituto da experiência real, confiando em que os fatos relatados não só ocorreram, como são relatados exatamente como aconteceram. Para Rouillé: "a máxima da reportagem clássica é, sem dúvida, a expressão mais avançada da concepção segundo a qual a imagem é a reprodução de uma coisa que é anterior a ela, de um exterior, de um - his paintings, towers and discoveries; to see things thousands of miles away, things hidden behind the walls and within rooms, things dangerous to come to; the women that men love and many children; to see and take pleasure in seeing; to see and be amazed; to see and be instructed. Thus to see, and to be shown, is now the will and new expectancy of half mankind. To see, and to show, is the purpose of this new magazine." (tradução livre da autora). 
original preexistente.” (ROUILLÉ, 2009, p. 73)

Este é o ponto de partida do conceito "isso foi", possível

[...] a partir do dia em que uma circunstância científica permitiu captar e imprimir diretamente os raios luminosos emitidos por um objeto diversamente iluminado. A foto é literalmente uma emanação do referente. De um corpo real, que estava lá, partiram radiações que vêm me atingir, a mim, que estou aqui” (BARTHES, 2012, p. 75).

Ou seja: é justamente a natureza científica da imagem-máquina que a confere credibilidade como substituta de seu referente.

Já foi dito neste artigo que a "imagem-máquina" tem sua credibilidade também por tomar a imagem de uma só vez e, assim, se adequar melhor ao tempo do homem moderno. Isso se soma, no fotojornalismo, com a ideia popularizada pelo fotógrafo Henri Cartier-Bresson (1908-2002) do "instante decisivo"; na reportagem clássica, segundo Rouillé (2009), isso implica na função do repórter, que consiste em "[ao confrontar-se com o acontecimento] 'andar em volta enquanto ele se desenvolve', em 'procurar a solução' (única) de sua multiplicidade e de sua variação [...] até, finalmente, 'captar o fato verdadeiro em sua relação com a realidade profunda."” (ROUILLÉ, 2009, p. 132)

Portanto, o instante decisivo também contribui para a ideia de "captura do real" pela fotografia. Mas esta captura está condicionada aos olhares do fotógrafo e de editores que, posteriormente, decidirão qual instante capta melhor "a verdade". Segundo Morris (2002), a busca do momento decisivo tornou-se a preocupação dos fotojornalistas, ou seja, resumir um evento como um todo em uma 
imagem de apenas um fragmento de segundo; isso é uma manipulação do evento, inerente ao jornalismo, mas que não deve ser tomada como verdade, como se presumia na fotografia-documento.

Luce, no editorial supracitado, buscava ser "testemunha ocular de grandes acontecimentos", e, a partir desta frase, podemos destacar as coberturas de guerras, da chegada do homem na lua e de tantos outros acontecimentos que marcaram o século XX. Mas, afinal, será que a fotografia-documento é testemunha?

Ao ser tomada como substituta do real, ela é muito mais uma "prova" do acontecimento, mostrando que "isso foi", do que uma testemunha, afinal, ao testemunhar algo, presumimos uma transformação do acontecimento, consciente ou não, por quem, no caso, o fotografou. Para o professor e pesquisador francês François Soulages:

Em que ela [testemunha] transforma, voluntariamente ou não, o fenômeno que quer fotografar? Um acontecimento existe não só em função de seu reconhecimento por uma testemunha, mas principalmente em função de sua constituição como acontecimento por essa testemunha, seja ela fotógrafo ou historiador. Não há acontecimento preexistente a seu reconhecimento. (SOULAGES, 2010, p. 35).

Disso, podemos inferir que a Life, ao reconstituir os acontecimentos em suas páginas se portando como "testemunha ocular", era parte fundamental para seu reconhecimento. É a importância conferida pela revista aos fatos que constituía o fato.

Mas este reconhecimento colocava o acontecimento sob a ideologia de quem o reconheceu, no caso, a revista Life. E, para Soulages, o problema disso é que 
[...] as fotos de tais reportagens não só praticamente inventam um mundo de sonhos, mas também participam da produção de uma ideologia massificante e alienante que, como toda ideologia, se pretende portadora de verdade. Tal fotografia produz um engodo que faz sonhar e não pensar. (SOULAGES, 2010, p. 36).

Quando inferimos que a fotografia mostra o real, como nos induz a pensar a fotografia-documento, corremos o risco de comprar a ideologia ${ }^{3}$ da revista como realidade, sem parar para refletir no que constrói a informação como real.

Para o fotógrafo norte-americano William Betsch (19392010), esta é uma questão estrutural no fazer do fotojornalismo, que “(quase) nunca consiste em mostrar o real, mas em suprimir do real aquilo que não corresponde à revista que paga, à imagem que ela tem do real." (BETSCH apud SOULAGES, 2010, p. 37). A alternativa a estas problemáticas está na fotografia-expressão, que, para Rouillé (2009), é quando a fotografia-documento compreende uma expressão, ou seja, reconhece a autoria do fotógrafo sobre sua imagem.

A partir do reconhecimento da autoria, podemos inferir, ao analisar uma imagem, que ela não representa o real, mas sim uma versão mediada por um autor. Partindo deste ponto, é mais difícil que se tome como verdade a ideologia de revistas como a Life e acredite que "isso foi", como propunha Roland Barthes (2012), e já se considere a hipótese de que "isso foi encenado", como propõe

3 Tomamos pelo conceito de ideologia a concepção marxista, por ser derivada da ideia positivista (e, por conseguinte, em congruência à ideia de fotografiadocumento); neste trabalho, o conceito é tomado como o conjunto de ideias da classe dominante (à qual Henry Luce pertencia e a Life reproduzia) convertido em ideia dominante para a sociedade como um todo, ou seja, tomar as ideias de uma classe e convertê-las em ideias gerais, como se boas para toda a sociedade. 
François Soulages (2010).

No início da Life, por exemplo, Luce preocupava-se muito com a qualidade das imagens e, por isso, seus fotógrafos iam a campo com câmeras de grande formato e utilizava o flash, o que impossibilitava a tomada de fotografias cândidas ${ }^{4}$ e fazia com que as fotos em geral fossem posadas. O posar nos coloca em situação de teatralização; como disse Barthes: "Diante da objetiva, sou ao mesmo tempo: aquele que eu me julgo, aquele que eu gostaria que me julgassem, aquele que o fotógrafo me julga e aquele de que ele se serve para exibir sua arte.” (BARTHES, 2012, p. 21).

Além disso, fotografias que tomamos como cândidas podem ter sido encenadas: a foto de Joe Rosenthal em Iwo Jima (figura 1), publicada na Life em 1945, não foi tomada no momento da ação: o fotógrafo pedira para os soldados reencenarem a colocada da bandeira como tinham feito no dia anterior para que ele pudesse fotografar e publicar na revista. A foto encenada foi tomada como real, colaborando com a ideologia da revista e "manipulando" o leitor que acreditara naquela foto como documento e prova do ocorrido.

4 Fotografias cândidas: ideia concebida pelo fotógrafo alemão Erich Salomon no início do século XX que consistia na tomada de imagens 'roubadas', ou seja, fotografias nas quais as pessoas não sabiam que estavam sendo fotografadas. 
Figura 1 - Fotografia de Iwo Jima usada como exemplo de encenação

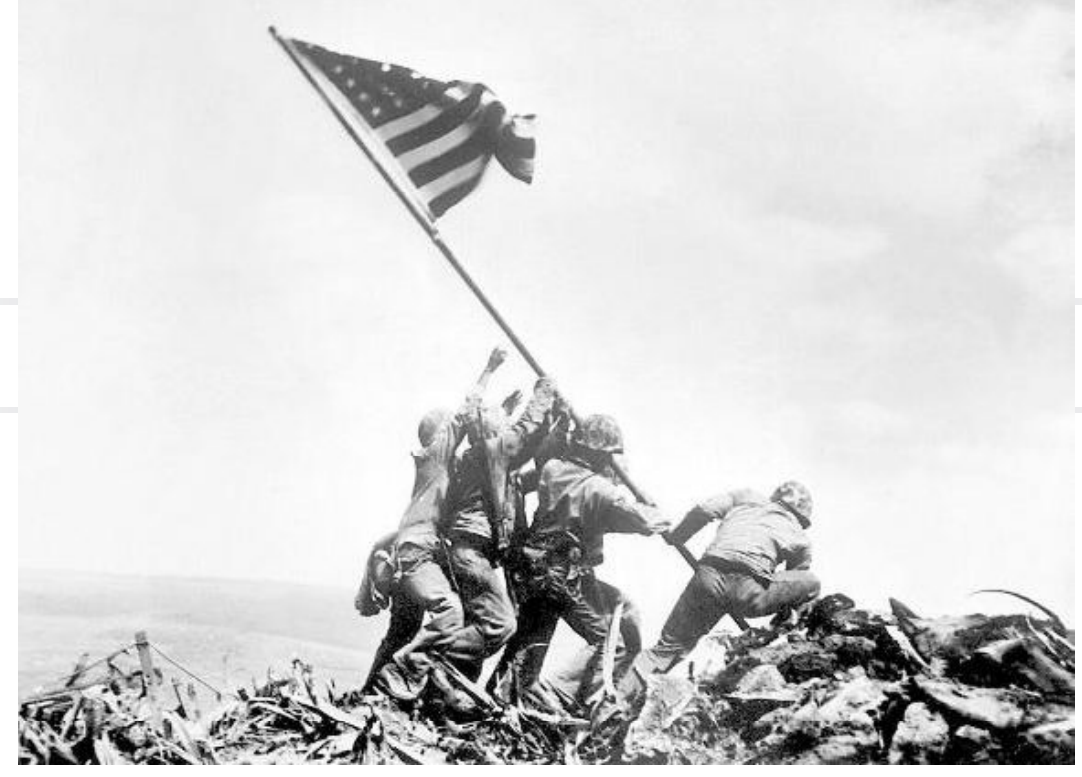

Fonte: Joe Rosenthal (1945)

A fotografia pode enganar tanto pela encenação no momento da tomada da imagem, como o caso de Rosenthal, como também posteriormente, na hora da revelação do negativo e da realização das cópias; podemos tomar como exemplo os casos de manipulação de imagens por Stálin na União Soviética, nas quais ele tirava antigos aliados políticos por manipulação nas fotos e, assim, os "apagava" da história e as usava como "provas" para identificar opositores do regime.

Mas, com tantas evidências de que a fotografia não é prova do real, quais as consequências desta crença no "isso foi"? Soulages (2010) nos responde esta pergunta dizendo que, devido à necessidade que temos de acreditar, acabamos caindo na ilusão de que existe uma prova graças à fotografia e, portanto, somos enganados (mais uma vez): "o isto se deixou enganar: nós fomos enganados." (SOULAGES, 2010, p. 26). A alternativa para o "isso foi" é a proposta 
de Soulages (2010) na teoria do "isso foi encenado": a ideia é interpretar a fotografia como passível de encenação, reconhecendo que tanto o fotógrafo quanto o fotografado estão em posição de encenação perante a fotografia, ao reconhecer que ambos imprimem suas visões de mundo, impressões e ideologias na fotografia. As ideias de "isso foi" e "isso foi encenado" serão exploradas nas próximas partes deste artigo.

\section{A máquina de fazer ver ${ }^{5}$}

Cada invenção é uma resposta às necessidades da sociedade em que surge. A fotografia não foi diferente: criada na França pelos inventores Louis Jacques Mandé Daguerre (1787-1851) e Joseph Nicéphore Niépce (1765-1833) e, paralelamente, pelo pintor e também inventor Hippolyte Bayard (1801-1887), também foi "inventada" contemporaneamente na Inglaterra pelo escritor e cientista William Henry Fox Talbot (1800-1877) e no Brasil pelo desenhista e inventor francês Hercule Florence (1804-1879).

Isso mostra que uma sociedade burguesa emergente precisava mecanizar o processo de produção de imagens e adequá-lo ao seu tempo. A preocupação inicial era com os retratos, afinal, os burgueses precisavam se afirmar na sociedade e usavam da maneira aristocrática para isso; no começo, com retratos em miniatura, mas, com a alta demanda e o alto preço cobrado, a fotografia foi uma invenção que veio suprir esta necessidade.

5 Termo escrito por André Rouillé no livro A Fotografia: Entre documento e arte contemporânea. 
Ao ser apresentada para a Academia de Ciências da França, outras utilidades surgiram para o novo meio de representação: o de documentar e catalogar descobertas científicas e antropológicas. Ao invento, até então chamado de Daguerreótipo, dado o nome do inventor que o patenteou, foi conferido o caráter de documento.

Esta denominação vem da ideia de que o novo invento copiava fidedignamente o que representava e se tornava uma "prova" da existência do fotografado. É justamente nesta concepção de "prova" que se apoiam as funções da fotografia-documento na sociedade moderna: arquivar as inúmeras descobertas, unificar territórios e conhecimentos, organizar os saberes desta nova sociedade e informar, função que é o principal objeto deste artigo.

Para Roland Barthes (2012), estas fotografias e suas funções são de interesse do studium, termo por ele conferido para designar as imagens das quais participamos culturalmente. Em suma, são as imagens que servem como testemunho da história ou da política. Segundo ele, estas fotografias são de interesse médio, que não nos causam tanto prazer, não nos "pungem".

Isso porque o que vemos nas fotografias é o referente em si, não uma imagem, então, para ele, temos de ter alguma relação em especial com o referente para que a imagem tenha um apelo maior para nós, Spectators. Este apelo é chamado de punctum, o que não existe em fotojornalismo, pois nós podemos nos comover com as fotos, mas não podemos estabelecer tanta relação. $\mathrm{O}$ fotojornalismo, portanto, seguindo a lógica de Roland Barthes, se limita ao studium. É a partir do studium que podemos pensar o conceito do "isso foi", chave para entendermos a fotografia-documento. Da foto como testemunha, podemos inferir que a imagem fotográfica mostra o que 
aconteceu de fato e diretamente; diferentemente da pintura ou da escrita, a "testemunha" fotográfica teve necessariamente de estar no local para criar o documento, dando credibilidade e dotando-o com o cunho de verdade; por isso, para Barthes, podemos afirmar que "isso foi”, também devido às condições técnicas e científicas da produção da fotografia.

E são justamente as condições técnicas e científicas, ou seja, a impressão feita pela luz do sol no papel ou vidro, que excluem, para o homem moderno, a subjetividade humana da fotografia, afinal, a imagem é captada por um aparelho, sem a manipulação do homem. Já em 1859, pouco tempo depois da invenção da fotografia, quando o escritor francês Charles Baudelaire (1821-1867) escreveu uma crítica ao Salão de Arte de Paris, podemos perceber a problemática da crença na falta de subjetividade do autor em fotografia.

Baudelaire dá como razão para o desinteresse pelas artes e pelo belo a busca pela reprodução exata do real, encontrada com a fotografia. Para ele, "os progressos da fotografia contribuíram bastante [...] para o empobrecimento do gênio artístico francês." (BAUDELAIRE, 1988, p. 72) No caso, a fotografia seria um resultado da busca das artes de uma reprodução mais fidedigna do real a partir do desinteresse pelo belo, o que era buscado por uma "multidão idólatra".

Esta recusa da fotografia, pretensamente por acreditar-se em seu excesso de verdade, na arte, parte da ideia de que a fotografia é transparente e mostra apenas seu referente, como Barthes (2012) postulou depois de um século do texto de Baudelaire (1988). É a fotografia que reproduz fielmente o real, a fotografia que nunca pode ser considerada arte, que é a chave do conceito de "isso foi" e da ideia da fotografia-documento. 
Barthes (2012) não considera a fotografia uma forma de arte por não acreditar na noção de autoria de um fotógrafo ${ }^{6}$, ao recusar a ideia de estilo de um artista. Como a fotografia é transparente e o que se vê nela é apenas seu referente, é impossível gostar de todas as fotos de um fotógrafo. Portanto, para a fotografia-documento, não existe a ideia de autoria do fotógrafo e, portanto, não importa quem faz a foto, mas sim seu referente. Isto impacta diretamente no fotojornalismo, ao lembrarmos que Luce, com a Life, queria ser "testemunha ocular dos grandes acontecimentos", como discutido na primeira parte do trabalho. Entramos então em um paradoxo: se a testemunha impacta diretamente no reconhecimento de algo, então como podemos recusar a sua subjetividade? Entretanto, assim é feito com a fotografia-documento e a noção de "isso foi", mas, mais precisamente, com a ideia barthesiana de fotografia unária.

A fotografia unária é, para Barthes, “quando (a fotografia) transmite enfaticamente a 'realidade, sem duplica-la, sem fazê-la vacilar." (BARTHES, 2012, p. 43). Esta frase encaixa-se perfeitamente na ideia de fotografia-documento ao pensarmos que, no documento, não existe a foto, mas sim o referente. Esta foto obviamente exclui toda e qualquer subjetividade do fotógrafo em detrimento de um pretenso ideal de verdade. É esta a fotografia do começo do fotojornalismo, a fotografia que serve para informar.

Mas a função informativa não é a única; esta fotografia serve também para arquivar, ordenar e fragmentar o que conhecemos do

6 A questão da autoria para Barthes (2012) é, em partes, controversa, pois, talvez por um problema na tradução, pode-se pensar que o autor não se coloca desta forma sobre a questão; porém, pontuamos que no livro de Soulages (2010), a tradução foi feita da mesma forma e a questão da autoria foi atribuída da mesma maneira para Barthes. 
mundo. Porém, estas funções também são observadas no jornalismo. Se pensarmos nas preocupações de Luce no editorial de publicidade da Life, ao desejar mostrar "coisas estranhas", "sombras na selva e na lua", "coisas escondidas entre paredes e dentro dos quartos", "coisas perigosas de aproximar-se", ele demonstra um certo desejo de catalogar, de fazer da sua revista um arquivo de imagens.

É ao descrever esta função da fotografia-documento que Rouillé (2009) escreve uma frase extremamente pertinente ao falarmos da Life: "a relação, às vezes perigosa, vivida com o mundo é delegada a um terceiro (o fotógrafo) e substituída pela relação visual com as imagens." (ROUILLÉ, 2009, p. 101) O americano não precisava ir à guerra para ser informado e conhecer visualmente seus horrores. Não precisa ir à lua para ver suas sombras. Não precisa ir até o acontecimento; ele vai até o spectator pelas páginas da revista.

Assim como o álbum, o jornalismo não somente arquiva como também ordena o que é relatado: ao compor as imagens em determinada sequência, ao determinar o tamanho de cada fotografia e de cada reportagem e ao ordenar as reportagens, produz-se sentido, constrói-se coerência, propõe uma visão e ordena simbolicamente o real.

Mas, mesmo dando ordem e coerência, o real não é mostrado como um todo; por isso, pode-se dizer que o fotojornalismo também fragmenta o real. Parece óbvio dizer que a fotografia é um fragmento, mas a fotografia-documento se propõe como um todo; podemos voltar à ideia defendida por Cartier-Bresson do "momento decisivo", quando ele afirma que a tarefa do repórter fotográfico se resume em "andar em volta" enquanto o acontecimento se desenvolve, "procurar a solução (única) de sua multiplicidade" até finalmente "captar o 
fato verdadeiro em sua relação com a realidade profunda." (ROUILLÉ, 2009, p. 132)

Ao se propor a captar o "fato verdadeiro" em apenas um instante decisivo, isso nos remete à ideia de fragmentação do real. Não existe uma solução única para toda a multiplicidade de um acontecimento e muito menos uma fotografia única tirada em uma fração de segundo que dê conta de representar um fato em toda sua completude sem nenhuma subjetividade envolvida, como é a proposta da fotografia-documento.

Junto a tudo isso, vem a principal função da fotografia-documento no fotojornalismo: informar. E nesta função, havia uma moral para a produção da reportagem. O fotógrafo se situava em posição de exterioridade perante o acontecimento e tentava ter o máximo de distanciamento da cena, interferir o mínimo Cartier-Bresson dizia ser preciso ter "patas de veludo", ou seja, participar sorrateiramente da cena para não ser percebido.

Esteticamente, temos como consequência as imagens cândidas, nas quais o fotografado não nota a presença do fotógrafo e age naturalmente, sem posar. Além disso, na moral da reportagem, a imagem era completa na sua tomada, sem cortes ou alterações posteriores no laboratório. A soma de tudo isso aumentava a credibilidade do fotojornalismo, que era tomado como substituto do real.

Para pensar assim, precisamos lembrar que, para a fotografia-documento, recusava-se a ideia de autoria e a subjetividade de um fotógrafo, então era plenamente possível acreditar que o fotógrafo estava fora da cena, não interferia e tinha distanciamento total do assunto. Juntando ao fato de se acreditar que não haviam interferências posteriores no laboratório, a moral da reportagem se liga facilmente 
à fotografia-documento e ao conceito barthesiano de "isso-foi". Não vemos a fotografia, vemos o acontecimento em si.

Entretanto, como foi falado no começo desta parte do trabalho, a invenção da fotografia foi uma resposta às necessidades da sociedade em que ela foi criada; seguindo esta lógica, quando muda a sociedade, mudam-se as necessidades. Na mudança da sociedade pós-industrial para a sociedade da informação, a fotografia-documento não conseguia responder tão bem ao que a nova organização social precisava e entrou em declínio.

Não se precisava mais de uma máquina de criar certezas; o mundo já fora mostrado, os acontecimentos, as sombras na selva e na lua, as mulheres que os homens amam e muitas crianças passaram exaustivamente pelas páginas das revistas ilustradas. E cada vez mais os fotógrafos mostravam seus trabalhos, se conheciam e se valorizavam. As histórias que queriam mostrar eram outras e, se aproveitado do grande valor do fotógrafo no final da Segunda Guerra Mundial (1939-1945), quatro fotojornalistas da Life resolveram fundar a primeira agência fotográfica: em 1947, surgiu a Magnum, criada por Robert Capa (1913-1954), Henri Cartier-Bresson, David Seymour (1911-1956) e George Rodger (1908-1995). Era o início da fotografia-expressão. 


\section{"Se existisse uma representação exata, eu não fotografaria"7}

A Magnum surgiu em 1947, mas a vontade de Capa de fundá-la, segundo John Morris (2002), era mais antiga: Capa sempre reclamava com seus colegas da Life sobre o domínio que a revista tinha sobre suas imagens, e desejava fundar uma cooperativa de fotógrafos para se tornarem mais independentes.

A ideia era simples: cada fotógrafo sugeria a pauta para a agência, que oferecia a representação internacional para vender as imagens às revistas. Assim, era o fotógrafo, não mais os editores, que escolhia o que e como ia fotografar. Na hora da venda e publicação das imagens, o fotógrafo que escolhia o corte posterior (se houvesse) e aprovava o texto.

A fundação da Magnum mostra uma transformação no fazer do fotojornalismo, que começava ali e se estenderia pelo período que aqui consideramos como o da fotografia-expressão, durante $o$ qual o fotógrafo mandava no próprio trabalho e tinha sua autoria reconhecida.

A criação da agência foi o ponto inicial de uma transformação gradativa na maneira de ver e fazer o fotojornalismo, o que não significou o fim da fotografia-documento de forma imediata; na verdade, o ápice do documento foi posterior à fundação da Magnum, com a Guerra do Vietnã (1955-1975).

As batalhas no Vietnã foram extensivamente cobertas pelas revistas ilustradas e os fotógrafos tinham papel central junto dos 7 (MAILLARD apud SOULAGES, 2010, p. 65). 
fronts, muitas vezes usando as mesmas roupas dos soldados, pulando com eles de paraquedas, enfim, participando ativamente da guerra durante a cobertura. Eles eram relativamente livres e independentes para fotografar o que quisessem, e a guerra foi coberta sem nenhum tipo de censura pelo exército.

Mas foi justamente este tipo de cobertura que levou o exército a perceber o poder da imagem. Com a extensiva publicação das imagens da guerra em revistas, muitas vezes contra a intervenção americana no Vietnã, muitos protestos foram incitados. Por isso, nas guerras posteriores, os fotógrafos eram completamente controlados pelos militares e obrigados a fotografar de um mesmo plano, de uma mesma forma. A estratégia, para Rouillé, visava impedir que acontecesse o mesmo que no Vietnã:

Conscientes dos efeitos que as imagens podiam ter sobre a opinião pública, sistematicamente os militares procuraram apoderar-se delas, tentando banir as tomadas a partir do chão, eliminar qualquer representação de corpos e de vítimas, rejeitar qualquer vestígio concreto de combate e, sobretudo, apresentar o conjunto do conflito sob a forma alienada de um imenso jogo eletrônico. A guerra tornava-se, assim, abstrata e aceitável; ou, até mesmo, aceita. (ROUILLÉ, 2009, p. 142).

Esta nova maneira de ver a fotografia de guerra é um contraponto à ideia de "isso foi", quando pensamos que a fotografia pode ser influenciada, sim, pelo ponto de vista e pode ser encenada. A frase do fotógrafo italiano Ando Gilardi (1921-2012) nos explica melhor como se dá esta relação: "Logo depois de tirada, a foto começa a se esvaziar de seu sentido ligado à atualidade representada 
para começar a ficar carregada de sentidos intencionais, isto é, aqueles estabelecidos por seu modo de divulgação" (GILARDI apud SOULAGES, 2010, p. 78).

A partir desta ideia, podemos inferir que uma foto tem sentidos intencionais, como, por exemplo, o sentido imposto pelo exército ao controlar enquadramentos, ângulos e temáticas da fotografia. Além disso, a maneira como a imagem é veiculada também altera seu sentido e sua forma de recepção, o que era muito usado pelas revistas ilustradas para impor sua ideologia para os leitores crentes no "isso foi".

Por causa de todas as restrições aplicadas, tanto pelos exércitos quanto pelas revistas, os fotógrafos queriam maior liberdade para fazer e vender seu trabalho, seu olhar. Queriam colocar uma expressão ao documento, lançar-se a novas maneiras de fazer fotojornalismo, permitirem as ambiguidades e múltiplas leituras da fotografia. E foram assim que surgiram as agências fotográficas, como a Magnum, nas quais os fotógrafos decidiam o que queriam fotografar e como queriam fotografar, além de interferirem diretamente caso algum editor alterasse o sentido desejado para a foto ou para a reportagem.

É a partir da ideia de que a foto produz sentido que surge a fotografia-expressão: "A uma fotografia-documento que compreende uma expressão, isto é, que engloba um acontecimento, nós chamaremos de "fotografia-expressão", (ROUILLÉ, 2009, p. 137) Ou seja: a fotografia-expressão não se desliga totalmente do documento, mas sim admite suas ambiguidades, suas múltiplas leituras, enfim, a fotografia como uma forma de representação.

A fotografia-expressão se apoia em uma tripla afirmação: a da subjetividade do fotógrafo, o que significa que o fotógrafo 
interfere na representação da cena e produz o sentido da imagem de acordo com o que acredita e com seu repertório individual; a das relações sociais e subjetivas com os modelos, o que contesta a ideia do repórter exterior ao acontecimento, as "patas de veludo" de Cartier-Bresson; e escrita fotográfica, que é justamente a afirmação de que a fotografia produz sentido.

Esta mudança foi possível apenas por uma mudança no regime de verdade. No início da subdivisão anterior, falamos que cada invenção é fruto de uma necessidade própria da época na qual surge; por isso, a fotografia-documento, criada em uma sociedade pós-industrial, uma sociedade de coisas, responde mal à sociedade da informação, uma sociedade de ideias. E estas mudanças, no jornalismo, resultaram em uma inversão da postura e da ética dos fotojornalistas: assim surgiu a ideia de roteirização da reportagem.

Para Rouillé, isso vem também do aumento da concorrência, motivo pelo qual

Muitos repórteres resolveram não mais percorrer o mundo atrás de furos, porém de construir suas imagens; de não mais seguir a atualidade, porém de antecipá-la ou comentá-la; de não mais dedicar um culto exclusivo ao instantâneo, porém de dar a seus personagens o direito de pose; de não mais enfrentar a realidade bruta, porém de encená-la (ROUILLÉ, 2009, p 143).

Nesta afirmação, podemos ver as principais características da fotografia-expressão: a possibilidade da encenação e da interferência do modelo, enfim, a liberdade para ele criar a maneira como deseja ser representado, sem ter sua imagem "roubada" pelo fotógrafo; e 
a possibilidade de criação e imposição do estilo e da escrita de um fotógrafo, não se prendendo mais em pretensos ideais de verdade. Finalmente a fotografia se apresenta como representação.

Estas características estão em comum com o contraponto estabelecido por Soulages (2010) à ideia de Barthes do "isso foi": é a concepção do "isso foi encenado". A encenação nada mais é do que admitir que a fotografia não capta o real, mas sim que está sob influências e pode ser manipulada ou encenada. Para Soulages, a fotografia "é sempre feita por um homem que é ele próprio trabalhado e dominado inconscientemente por modelos a serem reproduzidos ou a serem evitados, por pulsões e desejos. Todo fotógrafo é, portanto, quer queira quer não, um encenador, o Deus de um instante" (SOULAGES, 2010, p. 76).

Ou seja: é impossível a fotografia ser a cópia exata de um real, pois ela está sob a interferência do olhar do fotógrafo e é condicionada por inúmeros fatores, como enquadramento (que inclui ou exclui o que quer da cena, por exemplo). Além disso, a fotografia pode ser manipulada posteriormente ou encenada pelos modelos antes da tomada da imagem. A primeira foto encenada da história foi feita um ano após a invenção da fotografia, pelo inventor Hippolyte Bayard (figura 2), em 1840; a foto foi uma forma de protesto pelo reconhecimento de Daguerre (e não dele) como o inventor da fotografia. Desde então, muitas fotografias têm sido encenadas e tomadas como real; podemos lembrar a foto de Joe Rosenthal em Iwo Jima, já citada na primeira parte deste artigo. 
Figura 2 - Primeira fotografia encenada da história

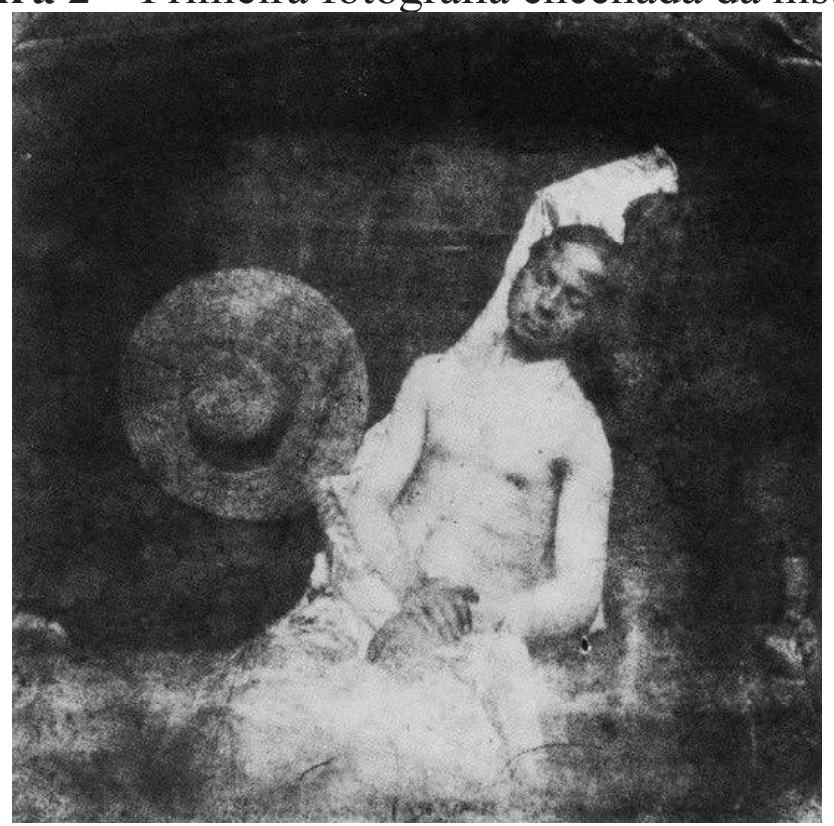

Fonte: Hippolyte Bayard (1840)

Mas não é só a manipulação anterior ou posterior à tomada da imagem que pode ser considerada encenação. Para Soulages,

Talvez seja - poder-se-ia dizer numa perspectiva humanista - a especificidade da encenação que manifesta o estilo do autor. Diante da foto de um anônimo, nunca podemos saber se essa foto é realmente de um anônimo espionado ou a de uma pessoa prevenida (que, portanto, representa): o "isso existiu" é impossível de dizer porque o "isto foi encenado" foi pronunciado uma vez. (SOULAGES. 2010, p. 76).

O que significa que a encenação pode partir tanto do estilo do autor quanto ser uma interação com o sujeito fotografado, que, por sua vez, encena. Por isso, temos sempre de decodificar a foto e suas diversas formas de encenação, próprias também da fotografiaexpressão e seu novo regime de verdade.

E com um novo regime de verdade, será que ainda temos as 
fotografias unárias? Será que ainda é possível que exista um sistema de representação que transmita enfaticamente a realidade, sem duplicá-la ou fazê-la vacilar?

Soulages (2010) não só critica a fotografia unária, como também contesta os motivos que nos levam a buscar um sistema de representação como substituto do real

É característica da fotografia o fato de ser potencialmente rica de um número infinito de sentidos: força explosiva da imagem rebelde - o que ignoram ou quiseram ignorar seus detratores. Essa vontade de ignorância, já observada, poderia ser explicada da mesma maneira que explicamos a vontade de realismo em alguns fotógrafos, ou seja, pela necessidade tranquilizadora de realidade, de verdade e de crença. (SOULAGES, 2010, p. 267).

Ou seja: a fotografia é plural e tem de ser interpretada como tal. Na fotografia-expressão, reconhecemos esta multiplicidade de leituras e sentidos, contrapondo a ideia de Barthes sobre as fotografias unárias.

Mas a fotografia-expressão não se afastou do documento, apenas lhe conferiu autoria e expandiu suas possibilidades. Tanto que consideramos neste trabalho a criação da Magnum como ponto inicial da fotografia-expressão, justamente por ser fruto da noção de autoria do próprio trabalho e vontade de domínio sobre a própria fotografia.

A escolha de um nome romano para a cooperativa também tem seu significado de imposição:

Para reivindicar sua independência e sua vontade de resistir às pressões das grandes agências comerciais de mídias, 
a cooperativa tinha de afirmar o alcance de sua ambição e o já renomado talento de seus membros. Ao escolher um nome com um toque "arcaico" era uma maneira de enobrecer um campo que ainda buscava reconhecimento e lutava por dignidade. (...) Além disso, Capa associou o nome "Magnum" com champagne [...] em qualquer caso, pelo menos até a morte de Capa, a agência celebrou cada um de seus inúmeros triunfos com uma destas voluptuosas garrafas [de champagne Magnum]. (MANCHESTER, 1989 , p. 48). ${ }^{8}$

Este trecho nos remete justamente ao motivo da criação da Magnum: a busca dos fotógrafos por reconhecimento, além da afirmação do talento de seus membros. Nada além do reconhecimento da autoria em suas fotos, próprio da fotografia-expressão. Como já citado no começo desta subdivisão do trabalho, a agência foi criada por fotógrafos da Life que desejavam maior independência em seus trabalhos e queriam se impor perante os editores, tanto propondo as pautas quanto criticando as edições.

É justamente este desejo por se mostrar como autor da imagem que caracteriza a Magnum como parte da fotografia-expressão e faz com que a agência seja sua grande representante.

8 "To assert its Independence and its will to resist the pressures of the major media agencies, the cooperative hat to affirm the scope of its ambition and the already renomed talent of its members. Choosing a name with na 'antique' touch was a way of enobling a field still searching for recognition and striving for dignity. [...] Finally, Capa associated the word "Magnum" with champagne [...] In any case, at least at least until Capa's death the agency celebrated each of its numerous triumphs by uncorking one of these voluptuously shaped bottles" (tradução livre da autora). 


\section{Considerações Finais}

Este trabalho buscou formar um panorama histórico da influência do conceito de autoria no fotojornalismo a partir de uma contraposição entre os conceitos de "isso foi", proposto por Barthes (2012), e "isso foi encenado", proposto por François Soulages (2010). Além disso, buscamos questionar a ideia de verdade em fotografia e mostrar o porquê se acreditava nisso, além de oferecer razões para discordarmos. Por fim, os exemplos da Life e Magnum foram escolhidos justamente para mostrar o quanto as diferentes ideias atuaram sobre os mesmos fotógrafos.

A partir desta comparação, podemos entender os perigos de se acreditar na fotografia como uma substituta do real e de não considerá-la uma representação, o que foi solucionado pela fotografia-expressão e ideia de "isso foi encenado". A parte mais importante é ressaltar a importância do reconhecimento da autoria do fotógrafo, fundamental no processo de produção e decodificação da imagem fotográfica.

\section{Referências}

BARTHES, Roland. A câmara clara. Rio de Janeiro: Nova Fronteira, 2012.

BAUDELAIRE, Charles. Salão de 1859. In: COELHO, Teixeira (comp.). A modernidade de Baudelaire. São Paulo: Paz e Terra, 1988. p. 59-74.

MANCHESTER, William. In our time: the world as seen by Mag- 
num photographers. Nova York: W. W. Norton \& Company, 1989.

MORRIS, John G. Get the picture: a personal history of photojournalism. 3. ed. Nova York: The University of Chicago Press, 2002.

ROUILLÉ, André. A fotografia: entre documento e arte contemporânea. São Paulo: Senac São Paulo, 2009.

SOULAGES, François. Estética da fotografia: perda e permanência. São Paulo: Senac São Paulo, 2010. 